\title{
Pengukuran Kinerja Perpustakaan Dengan Pendekatan Balanced Scorecard
}

\author{
Vera Devani ${ }^{1}$
}

\begin{abstract}
This research aims to investigate, identify and describe the performance level and the factor which impacts to the performance of the Perpustakaan Tun Seri Lanang (PTSL) using Balanced Scorecard approach. The descriptive analysis was used to proceed data on 4 perspectives, were financial, customer, internal business process and learning and growth, respestively. The questionnaires were distributed to 24 employees and 120 questionnaires were distributed to customers. The finding shosw that performance level of PTSL is in good category by the total score 41.75. Performance level of another perspective shows financial performance is very good by the total score 9, customer performance is good by the total score 3.62, internal business process performance is very good by the total score 8.79 and learning and growth performance is good by the total score the 19.34. Based on findings recommendation is formulated in order that PTSL should focus on employee productivity and customer satisfaction.
\end{abstract}

Keywords. Balanced Scorecard, costumer satisfaction, performance measurement.

\begin{abstract}
Abstrak. Penelitian ini bertujuan menyelidiki, mengidentifikasi dan menggambarkan tingkat kinerja dan faktor yang mempengaruhi kinerja Perpustakaan Tun Seri Lanang (PTSL) menggunakan pendekatan Balanced Scorecard. Analisis deskriptif digunakan untuk mengolah data pada 4 perspektif, yaitu keuangan, pelanggan, proses bisnis internal dan pembelajaran dan pertumbuhan. Kuesioner dibagikan kepada 24 karyawan dan 120 kuesioner didistribusikan kepada pelanggan. Temuan menunjukkan bahwa tingkat kinerja PTSL dalam kategori baik dengan total skor 41,75. tingkat kinerja dari perspektif lain menunjukkan kinerja keuangan yang sangat baik dengan total skor 9, kinerja pelanggan baik dengan total skor 3,62, kinerja proses bisnis internal sangat baik oleh total skor 8,79 dan pembelajaran dan kinerja pertumbuhan yang baik dengan total skor yang 19.34. Berdasarkan rekomendasi temuan diformulasikan agar PTSL harus fokus pada produktivitas karyawan dan kepuasan pelanggan.
\end{abstract}

Kata kunci. Balanced Scorecard, kepuasan pelanggan, pengukuran kinerja.

\section{Pendahuluan}

Pada masa sekarang, masyarakat sangat bergantung kepada informasi sebagai bagian dari kehidupannya. Tanpa ada informasi, kehidupan manusia tidak berjalan sebagaimana yang diinginkannya. Oleh itu, informasi pada masa sekarang menjadi sesuatu bahan komoditi yang sangat unggul. Siapa yang banyak menguasai informasi akan menguasai pengetahuan dan teknologi.

\footnotetext{
${ }^{1}$ Vera Devani, Jurusan Teknik Industri, Fakultas Sains dan Teknologi, UIN Sultan Syarif Kasim Riau, Jl. H.R.

Soebrantas No. 155, Km 15,5 Simpang Baru Panam,

Pekanbaru (28293) (email: veradevani@gmail.com).
}

Diajukan: 02-02-2016

Diperbaiki: 30-04-2016
Perpustakaan selama ini sering didefinisikan sebagai bangunan atau ruangan yang di dalamnya terdapat beberapa koleksi (Sutarno, 2004). Perpustakaan diukur berdasarkan jumlah bahan pustaka yang dimiliki atau perluasan bangunan perpustakaan. Penekanan lebih pada jumlah atau wadah, belum pada kualitas atau kandungan informasi yang dimiliki oleh perpustakaan. Sebagai organisasi yang memberi pelayanan, semestinya penilaian perpustakaan dilihat dari jumlah transaksi yang terjadi dan tingkat kepuasan pengguna.

Kualitas pelayananan perpustakaan dapat dilihat dari pengukuran kinerja. Pengukuran kinerja dapat didefinisikan sebagai sesuatu proses bagi menyediakan informasi mengenai sejauh mana sesuatu kegiatan tertentu telah dicapai, bagaimana perbedaan pencapaian itu dengan sesuatu standar tertentu untuk mengetahui apakah 
ada perbedaan diantara keduanya, serta bagaimana manfaat yang telah dikerjakan bila dibandingkan dengan harapan-harapan yang ingin diperoleh. Pengukuran prestasi adalah sesuatu komponen penting dalam proses perubahan, yang dapat memberikan umpan balik pada efektifitas rancangan dan pelaksanaan. Para manajemen dan akuntan bisnis menyadari pentingnya pengukuran kinerja dalam rancangan organisasi dan sistem kendali.

Pengukuran kinerja mengandung makna sesuatu proses atau sistem penilaian mengenai pelaksanaan kemampuan kerja suatu perusahaan atau organisasi berdasarkan standar tertentu (Kaplan \& Norton, 1996; Lingle \& Schiemann, 1996; Brandon \& Drtina (1997).

Penilaian kinerja melalui pendekatan balanced scorecard menggambarkan kinerja jangka pendek dan jangka panjang, keuangan dan non keuangan, internal dan eksternal. Kaplan dan Norton (2000) telah memperkenalkan sistem pengukuran kinerja tersebut. Balanced scorecard adalah sebuah sistem pengukuran kinerja yang komprehensif dari berbagai aspek, baik itu dari segi keuangan dan non keuangan, maupun aset yang tampak serta tidak tampak.

Pengukuran kinerja dengan pendekatan balanced scorecard digunakan oleh perusahaan atau organisasi berdasarkan visi dan misi organisasi (Ancella, 1996). Pengukuran prestasi dengan pendekatan balanced scorecard tidak hanya sebagai sesuatu sistem pengukuran saja, tetapi dapat berfungsi sebagai sistem pengukuran yang baru untuk mengkomunikasikan dan menghubungkan organisasi kepada strategi baru (Kaplan \& Norton, 2000).

Balanced scorecard tidak hanya digunakan oleh organisasi bisnis tapi juga oleh organisasi non profit. Balanced scorecard dapat membantu organisasi non profit dalam mengontrol keuangan dan mengukur kinerja organisasi (Modell, 2004). Organisasi pemerintah atau non profit adalah organisasi yang didirikan dengan tujuan memberikan pelayanan kepada masyarakat. Keberhasilan organisasi pemerintah atau non profit diukur melalui efektivitas dan efisisensi dalam memberikan pelayanan kepada masyarakat. Dengan kata lain kesuksesan bukan terletak pada pencapaian finansial tetapi kepuasan pelanggan. Dengan menggunakan pendekatan balanced scorecard organisasi pemerintah atau organisasi non profit dapat melakukan penilaian kinerja jangka pendek maupun jangka panjang.

\section{Pengukuran kinerja}

Kinerja merupakan gambaran mengenai tingkat pencapaian pelaksanaan suatu program kegiatan atau kebijakan dalam mewujudkan sasaran, tujuan, visi dan misi organisasi yang dituangkan melalui perencanaan strategis suatu organisasi. Pengukuran kinerja atau performance merupakan gambaran mengenai tingkat pencapaian pelaksanaan sesuatu program kegiatan atau kebijakan dalam mewujudkan sasaran, tujuan, visi dan misi organisasi yang dituangkan melalui perencanaan strategis suatu organisasi.

Menurut Mulyadi (2001), penilaian kinerja dimanfaatkan oleh manajemen untuk mengelola operasi organisasi secara efektif dan efisien melalui pemotivasian karyawan secara maksimum, membantu pengambilan keputusan yang bersangkutan dengan karyawan seperti promosi, transfer dan pemberhentian, mengidentifikasi kebutuhan dan pengembangan karyawan, serta untuk menyediakan umpan balik bagi karyawan mengenai bagaimana atasannya menilai kinerja mereka dan menyediakan suatu dasar bagi distribusi penghargaan.

Prinsip-prinsip dalam pengukuran kinerja (Hansen dan Mowen, 1995 yang dikutip oleh Yamit, 2005) adalah: (1) konsistensi dengan tujuan perusahaan, (2) memiliki adaptabilitas pada kebutuhan, (3) dapat mengukur aktivitas yang signifikan, (4) mudah untuk dipublikasikan, (5) akseptabilitas dari atas ke bawah, (6) biaya yang digunakan efektif, dan (7) tersaji tepat waktu.

Tujuan pokok penilaian kinerja adalah untuk memotivasi karyawan dalam mencapai tujuan organisasi dan dalam mematuhi standar perilaku yang telah ditetapkan sebelumnya agar membuahkan tindakan dan hasil yang diinginkan.

\section{Kepuasan kerja}

Kepuasan kerja merupakan hasil daripada berbagai sikap yang dipegang oleh seseorang terhadap pekerjaannya dan terdapat faktor-faktor yang berkaitan dengannya, dengan kata lain bahwa seseorang yang puas dengan kerjanya karena pekerjaannya dilihat sebagai kenikmatan sebagaimana seseorang bermain. $\mathrm{Hal}$ ini 
dihasilkan dari persepsi masing-masing individu terhadap pekerjaannya, didasarkan kepada faktor lingkungan kerja, seperti gaya penyelia, kebijakan dan prosedur, kerja kelompok, keadaan kerja dan tunjangan.

Kepuasan kerja merujuk kepada perasaan positif terhadap pekerjaan yang sesuai dengan kemampuan dan kemahiran individu di tempat kerja yang menyenangkan, diwujudkan oleh sikap dan semangat kerja yang tinggi dalam melaksanakan pekerjaan untuk memenuhi keperluan yang sama ada bagi individu ataupun bagi organisasi. Setiap individu memiliki tahapan kepuasan yang berbeda-beda sesuai dengan nilai yang dimiliki individu berkenaan.

Faktor intrinsik yang menjadi penentu kepuasan kerja ialah keperluan dan harapan karyawan itu sendiri terhadap organisasi. Ini dimaksudkan jika keperluan karyawan boleh dipenuhi dengan baik dan cita-citanya disalurkan sesuai dengan tempat bekerja, maka individu tersebut akan merasa dihargai sehingga dia akan memperoleh kepuasan daripada apa yang dilakukannya

Lima dimensi yang digunakan untuk mengukur kepuasan kerja, (Gibson, dkk., 1995) meliputi: (1) pembayaran, yaitu sesuatu angka yang diterima dan keadaan yang dirasakan dari pembayaran, (2) pekerjaan, yaitu sejauh mana pekerjaan dianggap menarik dan memberi kesempatan belajar dan menerima tanggung jawab, (3) kesempatan promosi, yaitu kesempatan untuk maju dan berkembang, (4) penyelia, yaitu sejauh mana penyelia memperhatikan pekerja, dan (5) rekan kerja, yaitu sejauh mana rekan kerja bersahabat, cekap dan menyokong.

\section{Kepuasan pelanggan}

Parasuraman, dikutip oleh Tjiptono (2008), menerangkan bahwa kualitas lima (5) dimensi, yaitu: (1) tangibles (bukti langsung) meliputi fasilitas fisik, perlengkapan, pegawai dan sarana, (2) reliability (kehandalan) yaitu kemampuan memberikan pelayanan yang dijanjikan dengan segera dan akurat, (3) responsiveness (daya tanggap), yaitu keinginan para staf untuk membantu para pelanggan dan memberikan pelayanan dengan tanggap, (4) assurance (jaminan) yang mencakup pengetahuan, kemampuan, kesopanan, dan sifat dipercaya yang dimiliki para staf, bebas dari bahaya, risiko atau keragu-raguan, dan (5) empathy (empati), meliputi kemudahan dalam melakukan hubungan, komunikasi yang baik, perhatian pribadi, dan memahami kebutuhan para pelanggan.

Menurut penelitian yang dilakukan oleh Parasuraman, dkk dikutip oleh Tjiptono (2008) disimpulkan bahwa dari kelima dimensi tersebut terdapat kepentingan relatif yang berbeda-beda. Keandalan dalam hal ini secara konsisten merupakan dimensi yang paling kritis kemudian pada tingkat kedua diduduki oleh kepastian, ketiga oleh keberwujudan, keempat oleh ketanggapan, dan dimensi terakhir yang memiliki kadar kepentingan paling rendah yaitu empati.

\section{Laporan keuangan}

Laporan keuangan akan memberikan gambaran kepada pihak yang berkepentingan untuk menentukan keputusannya. Laporan keuangan adalah dua daftar yang disusun oleh akuntan pada akhir periode untuk suatu perusahaan. Kedua daftar itu adalah daftar neraca atau daftar posisi keuangan dan daftar pendapatan atau daftar rugi-laba. Pada akhir-akhir ini sudah menjadi kebiasaan bagi perseroan-perseroan untuk menambahkan daftar ketiga yaitu daftar surplus atau daftar laba yang dibagikan (Myer dikutip oleh Munawir, 1993).

Laporan keuangan adalah suatu gambaran posisi keuangan perusahaan/ organisasi yang pada saat tertentu (akhir periode akuntansi) dan hasilhasil yang telah dicapai perusahaan/organisasi selama periode yang berakhir pada saat tertentu. Dua laporan utama yaitu neraca dan laporan rugilaba, di samping adanya laporan-laporan

Tabel 1. Analisa Laporan Keuangan

\begin{tabular}{|c|c|c|c|c|c|c|c|}
\hline Pos-Pos Neraca/ & \multicolumn{2}{|c|}{31 Desember } & \multicolumn{2}{|c|}{ Kenaikan/Penurunan } & \multirow{2}{*}{ Ratio } & \multicolumn{2}{|c|}{$\%$ dari Total } \\
\cline { 2 - 8 } Rugi-Laba & $200 \mathrm{X}$ & $200 \mathrm{Y}$ & $\mathrm{Rp}$ & $\%$ & & $200 \mathrm{X}$ & $200 \mathrm{Y}$ \\
\hline & & & & & & & \\
& & & & & & & \\
\end{tabular}


keuangan lain seperti laporan sumber dan penggunaan dana, laporan tentang modal pemilik dan daftar-daftar penjelasan penyokong.

\section{Analisa pembanding laporan keuangan}

Neraca menunjukkaan aktiva, hutang dan modal perusahaan/organisasi pada suatu saat tertentu, dengan demikian Neraca yang diperbandingkan menunjukkan aktiva, hutang serta modal perusahaan/organisasi pada dua tanggal atau lebih untuk satu perusahaan/ organisasi atau pada tanggal tertentu untuk dua perusahaan/organisasi yang berbeda. Dengan memperbandingkan neraca untuk dua tanggal atau lebih akan dapat diketahui perubahanperubahan yang terjadi.

Metoda analisis pembanding laporan keuangan dapat ditunjukan dalam (Munawir, 1993): (1) data absolut, (2) kenaikan dan penurunan, (3) perbandingan yang dinyatakan dalam ratio, dan (4) dinyatakan dalam persentase dari total.

\section{Balanced scorecard}

Balanced scorecard sebagai suatu sistem manajemen kinerja memberikan penekanan yang seimbang pada aspek keuangan dan keuangan dari empat perspektif, yaitu keuangan, pelanggan, proses bisnis internal dan pembelajaran/pertumbuhan. (Gaspersz, 2003 dikutip oleh Erlina, 2009). Balanced scorecard dapat berfungsi sebagai critical performance indicators, yaitu pengukuran yang memberikan indikasi kinerja organisasi atau perusahaan pada key success factors.

Definisi yang lain dikemukakan oleh Supriyono (2000) menyatakan, bahwa balanced scorecard adalah salah satu alat pengukuran kinerja yang menekankan pada keseimbangan antara ukuran-ukuran strategis yang berlainan satu sama lain dalam usaha untuk mencapai keselarasan tujuan sehingga mendorong karyawan bertindak demi kepentingan terbaik perusahaan.

Pearson dan Robinson (2007) dikutip oleh Wicaksono (2013) mendefinisikan balanced Scorecard sebagai satu kumpulan dari empat ukuran yang berkaitan langsung dengan strategi suatu perusahaan: kinerja keuangan, pengetahuan mengenai pelanggan, proses bisnis internal, serta pembelajaran dan pertumbuhan.
Keunggulan pendekatan balanced scorecard dalam sistem perencanaan strategis adalah mampu menghasilkan rencana strategis yang memiliki karakteristik sebagai berikut (Mulyadi, 2001 dikutip Erlina, 2009): (1) Komprehensif, dimana balanced scorecard memberikan masukan secara komprehensif dalam perencanaan strategi, tidak hanya fokus perspektif keuangan tetapi juga mencakup perpektif yang lain yaitu pelanggan, proses bisnis internal dan pembelajaran/pertumbuhan, (2) Koheren, dimana manajemen dituntut mampu membangun hubungan sebab akibat dari berbagai perspektif, (3) Seimbang, dimana sasaran strategi dirumuskan seimbang dari keempat perspektif dengan tujuan untuk pencapaian sasaran jangka panjang, dan (4) Terukur, dimana sasaran strategi disusun secara terukur, sehingga mudah untuk mengevaluasinya.

Beberapa manfaat dari konsep pengukuran kinerja balanced scorecard yaitu (Kaplan, 2000): (1) mengklarifikasi dan menghasilkan konsensus untuk strategi, (2) mengkomunikasikan strategi ke seluruh perusahaan, (3) menyelaraskan berbagai tujuan departemen dan pribadi dengan strategi perusahaan, (4) mengkaitkan berbagai tujuan stategis dengan sasaran jangka panjang dan anggaran tahunan, (5) mengidentifikasikan dan menyelaraskan berbagai inisiatif strategis, (6) melaksanakan peninjauan ulang strategis secara periodik dan sistematis, dan (7) mendapatkan umpan balik yang dibutuhkan untuk mempelajari dan memperbaiki strategi.

Beberapa kelemahan Balanced Scorecard menurut Anthony dan Govindarajan (2005) dikutip oleh Tandiotong (2011) adalah :

1. Korelasi yang buruk antara ukuran non keuangan dengan hasilnya. Tidak adanya jaminan bahwa profitabilitas masa depan akan mengikuti pencapaian target dibidang non keuangan manapun. Hal ini menjadi masalah karena adanya asumsi yang melekat bahwa profitabilitas masa depan mengikuti pencapaian individual.

2. Terpaku pada hasil keuangan. Sering kali para manejer terbiasa dan terlatih dengan ukuran keuangan, tetapi mereka juga sering mendapatkan tekanan-tekanan dari pemegang saham berkaitan dengan kinerja keuangan perusahaan mereka. Program insentif dapat menciptakan suatu tekanan tambahan bagi 
para manajer senior karena adanya pemberian kompensasi yang diberikan dengan berdasarkan kinerja keuangan.

\section{Perspektif pada balanced scorecard}

Balanced scorecard mengukur empat perspektif yang berbeda tetapi mempunyai tujuan yang sama yaitu mencapai sasaran strategi yang sudah direncanakan oleh perusahaan. Keempat perspektif tersebut saling berkaitan yang nantinya akan berusaha meningkatkan kinerja perusahaan. Empat perspektif pada balanced scorecard dapat dilihat pada Gambar 1.

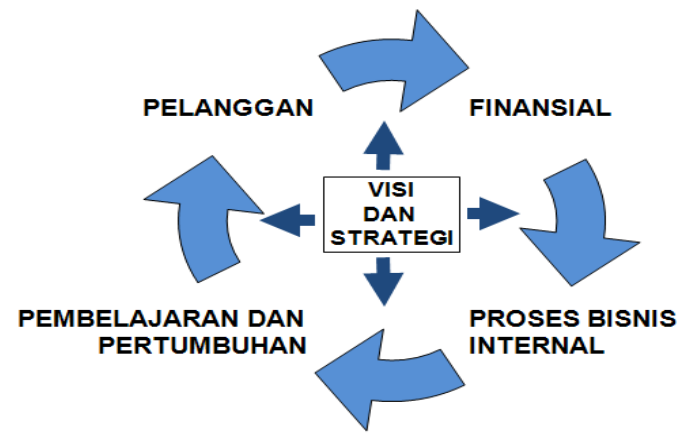

Gambar 1. Perspektif dalam balanced scorecard

(Sumber: Kaplan \& Norton, 2000)

Perspektif keuangan (financial perspective). Dalam balanced scorecard, perspektif keuangan tetap menjadi perhatian, karena ukuran keuangan merupakan suatu ikhtisar dari konsekuensi ekonomi yang terjadi yang disebabkan oleh keputusan dan tindakan ekonomi yang diambil. Pengukuran kinerja keuangan menunjukkan apakah perencanaan, implementasi dan pelaksanaan dari strategi memberikan perbaikan yang mendasar.

Perspektif pelanggan (customer perspective). Dalam perspektif pelanggan, balanced scorecard melihat aspek pelanggan memainkan peranan penting dalam kehidupan perusahaan. Sebuah perusahaan yang tumbuh dan tegar dalam persaingan tidak akan mungkin survive apabila tidak didukung oleh pelanggan. Loyalitas tolok ukur pelanggan dilakukan dengan terlebih dahulu melakukan pemetaan terhadap segmen pasar yang akan menjadi target atau sasaran. Apa yang menjadi keinginan dan kebutuhan para pelanggan menjadi hal yang penting dalam perspektif ini.

Perspektif proses internal bisnis (internal business process perspective). Perspektif proses internal bisnis lebih menekankan pada penciptaan produk baru yang lebih berkualitas sampai produk tersebut siap diedarkan kepada pelanggan. Tentunya proses internal bisnis tidak lepas dari perspektif keuangan dan perspektif pelanggan. Untuk mengoperasikan perspektif proses internal bisnis ini perusahaan harus lebih dahulu melihat keuangan perusahaan dan kemauan pelanggan. Jadi seakan-akan ketiga perspektif ini membentuk rantai yang saling berhubungan.

Perspektif pembelajaran dan pertumbuhan (learning and growth perspective). Dalam perspektif ini perusahaan berusaha mengembangkan tujuan dan ukuran yang mendorong pembelajaran dan pertumbuhan suatu perusahaan. Tujuan dari perspektif ini adalah menyediakan infrastruktur yang memungkinkan tujuan yang berkaitan dengan ketiga perspektif lainnya dapat terwujud, sehingga pada akhirnya akan dapat tercapai tujuan perusahaan. Tujuan perspektif ini merupakan faktor pendorong dihasilkannya kinerja yang istimewa dalam perspektif keuangan, pelanggan (customer), dan proses internal bisnis.

\section{Metodologi}

Metodologi yang digunakan dalam penelitian ini adalah metoda deduktif merupakan teori-teori yang berlaku dan metoda induktif merupakan hasil penelitian di lapangan. Digunakannya dua metoda ini dimaksudkan untuk saling melengkapi antara metoda tersebut, sehingga diharapkan hasil penelitian yang diperoleh dapat lebih lengkap.

Sedangkan sumber data yang diperlukan dalam penelitian ini adalah data primer dan data sekunder. Sumber data primer diperoleh dari hasil penelitian secara empirik melalui kuesioner kepada 24 orang karyawan dan 120 orang pelanggan perpustakaan. Data sekunder diperoleh dari laporan tahunan perpustakaan, yaitu anggaran dan pengeluaran.

Pengujian validitas kuesioner dapat dilihat pada corrected item - total correlation tampilan SPSS uji reliabilitas. Corrected item - total correlation adalah korelasi antara item bersangkutan dengan total item. Secara umum, jika nilai corrected item - total correlation lebih besar dari 0,2 maka pertanyaan tersebut dapat dikatakan valid (Lupiyoadi, 2006). Uji reliabilitas kuesioner dilakukan dengan 
menggunakan cronbacht alpha. Jika cronbacht alpha hasil uji > 0.6 maka pengukuran yang dilakukan andal atau instrumen reliabel (Ghozali, 2001 dikutip Sugiyono, 2008).

Analisis deskriptif menggunakan empat perspektif, yaitu perspektif keuangan, perspektif pelanggan, perspektif proses bisnis internal serta perspektif pembelajaran dan pertumbuhan. Pengukuran kinerja kepuasan kepuasan pelanggan mengadoptasi model Servqual (Parasuraman, dkk., dikutip oleh Tjiptono, 2008). Model Servqual menekankan kepada lima dimensi utama yaitu berwujud (tangibles), keandalan (reliability), ketanggapan (responsiveness), jaminan (assurance), dan empati (empaty). Untuk mengukur kinerja berdasarkan persepektif proses bisnis internal serta pembelajaran dan pertumbuhan menggunakan kuesioner yang disebarkan kepada karyawan perpustakaan. Sedangkan untuk mengukur kinerja keuangan dengan menggunakan data anggaran dan pengeluaran. Berdasarkan laporan keuangan tersebut dilakukan analisa perbandingan laporan keuangan dari setiap pos pengeluaran dengan menghitung kenaikan /penurunan dari setiap pos dan kemudian dibandingkan dengan realisasi anggaran.

\section{HASIL DAN PEMBAHASAN}

Data hasil pengukuran prestasi PTSL dengan menggunakan pendekatan balanced scorecard yang meliputi kinerja keuangan, pelanggan, proses bisnis internal serta pembelajaran dan pertumbuhan dapat dilihat pada bagian berikut ini.

\section{Pengukuran kinerja berdasar tingkat kepuasan pelanggan}

Untuk mengukur tingkat kepuasan pelanggan digunakan teori service quality (Gapersz, 1997). Setelah data diolah akan diperoleh skor harapan dan skor persepsi. Apabila skor persepsi dikurangi skor harapan menghasilkan skor gap positif berarti tingkat pelayanan melebihi harapan pelanggan atau dengan kata lain pelayanan sangat memuaskan. Sebaliknya, jika skor negatif, menunjukkan tingkat pelayanan lebih rendah dan jika gap sama dengan nol, berarti tingkat pelayanan sama dengan harapan pelanggan. Adapun kriteria kualitas dan tingkat kepuasan pelanggan ditampilkan pada Tabel 2.

Data mengenai skor persepsi, harapan dan gap pada masing-masing dimensi kualitas pelayanan dapat dilihat pada Tabel 3.

Dari Tabel 3, dapat kita lihat bahwa semua indikator pelayanan mempunyai gap negatif, artinya pelayanan yang diberikan masih di bawah yang diharapkan oleh pelanggan. Tingkat kepuasan pelanggan (TKP) untuk indikator kualitas pelayanan memberikan nilai berwujud $82,23 \%$, keandalan 69,09\%, ketanggapan $74,48 \%$, jaminan $74,53 \%$, dan empati $75,71 \%$. Hal ini menunjukkan bahwa tingkat kepuasan pelanggan untuk indikator berwujud adalah baik, indikator keandalan adalah agak tidak baik sedangkan indikator ketanggapan, jaminan dan empati adalah agak baik. Hal tersebut dapat juga dilihat dari total kepuasan pelanggan yang menunjukkan nilai $75,97 \%$ yang berarti tingkat kepuasan pelanggan adalah agak baik, dengan gap $-1,14$ berarti kualitas pelayanan yang diberikan sangat tidak baik. Berdasarkan tingkat gap dapat dilihat bahwa tingkat pelayanan yang

Tabel 2. Kategori kualitas dan tingkat kepuasan pelanggan

\begin{tabular}{|c|c|}
\hline Kualitas (Nilai Negatif) & Tingkat Kepuasan Pelanggan \\
\hline $0,0-0,1=$ Sangat baik & $<50 \%=$ Sangat tidak baik \\
\hline $0,2-0,3$ & $50 \%-59 \%=$ Tidak baik \\
\hline$=$ Agak baik & $60 \%-69 \%=$ Agak tidak baik \\
\hline$=$ Agak tidak baik & $70 \%-79 \%=$ Agak baik \\
\hline$=$ Tidak baik & $80 \%-89 \%=$ Baik \\
\hline$=$ Sangat tidak baik & $>90 \%=$ Sangat baik \\
\hline
\end{tabular}


Tabel 3. Kategori kualitas dan tingkat kepuasan pelanggan

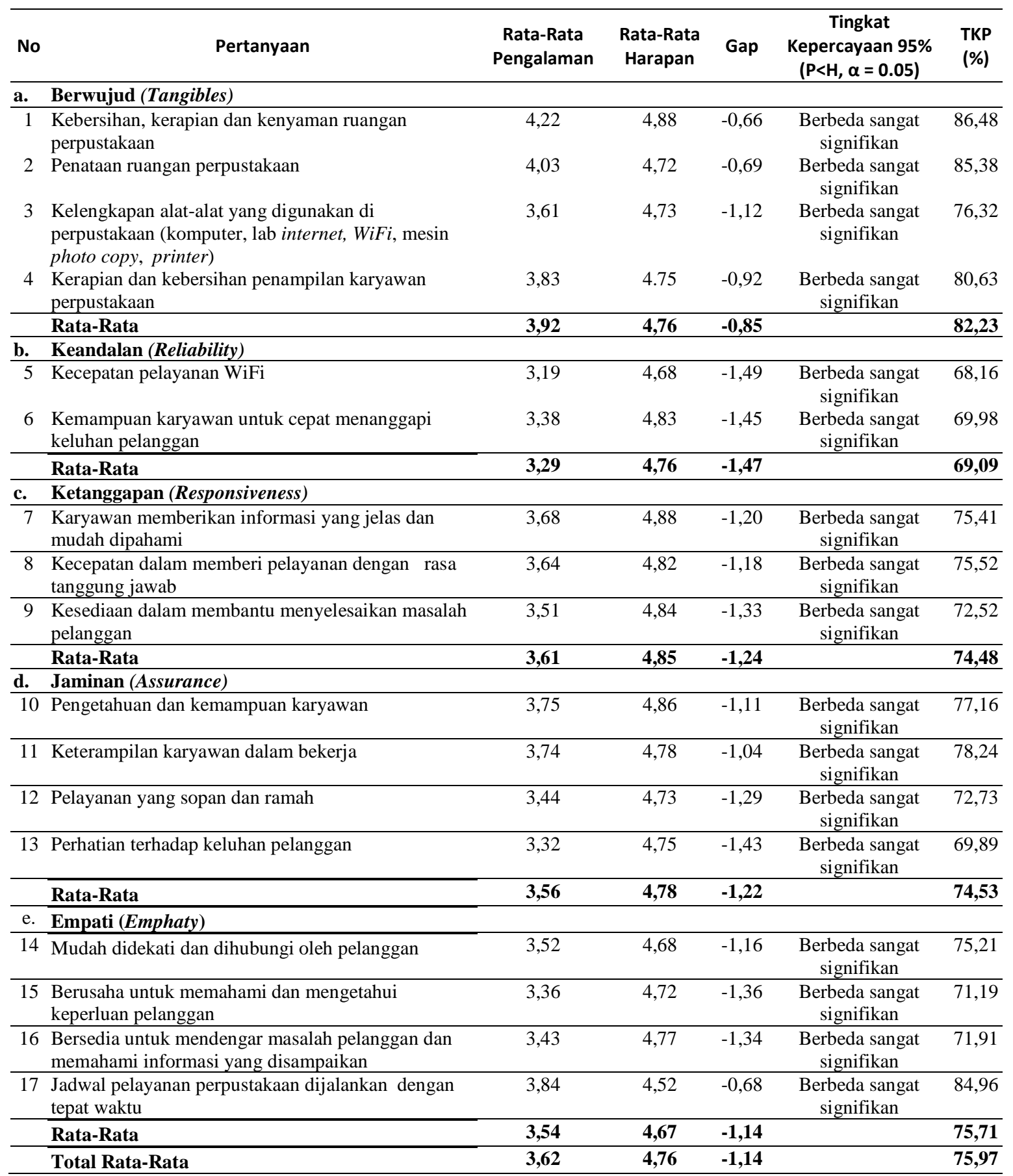

diberikan lebih rendah daripada harapan pelanggan.

pelanggan.

Berdasarkan uji $\mathrm{t}$, dengan tingkat kepercayaan 95\%, $\mathrm{v}=16$ maka $\mathrm{t}_{\text {Tabel }}=2,120$ dan $\mathrm{t}_{(0.975,16)}=-17,526$ dapat disimpulkan bahwa terdapat perbedaan antara persepsi dan harapan
Pengukuran kinerja berdasar interval skala

Berdasarkan Tabel 4 akan ditunjukkan hasil pengukuran dan skor untuk seluruh indikator yang dinilai dengan asumsi bahwa setiap 
Tabel 4. Hasil pengukuran kinerja perpustakaan

\begin{tabular}{|c|c|c|c|}
\hline Indikator Yang Diukur & $\begin{array}{c}\text { Hasil } \\
\text { Pengukuran }\end{array}$ & $\begin{array}{c}\text { Skor } \\
(1-5)\end{array}$ & Keterangan \\
\hline \multicolumn{4}{|l|}{ I. Kinerja Keuangan } \\
\hline 1. Pengeluaran dan penggunaan & 100,00 & 5,00 & Sangat baik \\
\hline \multirow[t]{2}{*}{ 2. Kualitas pelayanan } & 80,00 & 4,00 & Baik \\
\hline & Total Skor & 9,00 & Sangat baik \\
\hline \multicolumn{4}{|l|}{ II. Kinerja Pelanggan } \\
\hline \multirow[t]{2}{*}{ 1. Kepuasan pelanggan } & 75,97 & 3,62 & Baik \\
\hline & Total Skor & 3,62 & Baik \\
\hline \multicolumn{4}{|l|}{ III. Kinerja Proses Bisnis Internal } \\
\hline 1. Inovasi & 75,83 & 3,79 & Baik \\
\hline \multirow[t]{2}{*}{ 2. Kegiatan } & 90,00 & 5,00 & Sangat baik \\
\hline & Total skor & 8,79 & Sangat baik \\
\hline \multicolumn{4}{|l|}{$\begin{array}{l}\text { IV. Kinerja Pembelajaran dan Pertumbuhan } \\
\text { 1. Kemampuan perpustakaan }\end{array}$} \\
\hline \multicolumn{4}{|l|}{ 1. Kemampuan perpustakaan } \\
\hline b. Tingkat produktivitas karyawan & 70,63 & 3,53 & Baik \\
\hline c. Tingkat kemampuan mempertahankan karyawan & 84,58 & 4,23 & Sangat baik \\
\hline 2. Kemampuan sistem informasi & 73,61 & 3,68 & Baik \\
\hline \multirow[t]{3}{*}{ 3. Motivasi dan pemberdayaan } & 77,08 & 3,85 & Baik \\
\hline & Total skor & 19,34 & Baik \\
\hline & Total & 41,75 & Baik \\
\hline
\end{tabular}

indikator mempunyai bobot yang sama. Hasil pengukuran yang dimaksud adalah rata-rata nilai pengukuran responden terhadap suatu indikator yang terdiri dari sejumlah pertanyaan. Skor adalah elemen yang diukur dari hasil pengukuran berdasarkan interval skala.

Apabila dilihat secara keseluruhan kinerja perpustakaan adalah baik. Hasil kinerja keuangan berada dalam keadaan sangat baik. Kinerja keuangan berkaitan sangat erat dengan kinerja yang lainnya. Untuk itu, yang perlu ditingkatkan lagi adalah kinerja pelanggan serta kinerja pembelajaran dan pertumbuhan, terutama tingkat produktivitas karyawan walaupun secara keseluruhan kinerja pembelajaran dan pertumbuhan berada dalam keadaan baik. Secara keseluruhan, kinerja proses bisnis internal dinilai sangat baik, dimana inovasi dinilai baik dan kegiatan yang dilakukan oleh perpustakaan dinilai sangat baik.

Pengukuran kinerja dengan pendekatan balanced scorecard berkaitan antara satu perspektif dengan perspektif lainnya, yaitu jika kinerja pembelajaran dan pertumbuhan baik, maka kinerja proses bisnis internal dan keuangan akan baik pula sehingga pelanggan akan berpuas hati karena perpustakaan dapat memberikan pelayanan yang terbaik. Walau ada beberapa karyawan yang merasa tidak berpuas hati baik dengan manajemen perpustakaan ataupun karena sarana dan prasarana untuk kenyamanan mereka bekerja, tetapi mereka tetap bekerja dengan baik dengan standar kerja yang ada. Hal ini dikarenakan mereka merasa berguna bagi kalayak ramai.

Dalam menghadapi era globalisasi perpustakaan tidak hanya merasa puas dengan hasil yang telah mereka capai. Mereka harus terus menerus melakukan perbaikan terutama tingkat kepuasan pelanggan serta produktivitas karyawan. Kemampuan yang besar dapat dicari dengan memperhatikan semua aspek sehingga semua perspektif semakin baik. Dengan mengetahui kinerja perpustakaan secara komprehensif maka pihak manajemen dapat menggali potensi yang ada yang belum diperhatikan selama ini.

\section{SIMPULAN}

Berdasarkan pembahasan tersebut di atas, maka dapat dibuat kesimpulan:

1. Hasil pengukuran kinerja perpustakan dengan pendekatan balanced scorecard secara keseluruhan berada pada kategori baik dengan total skor 41,75.

2. Tingkat kinerja dari masing-masing perspektif adalah kinerja keuangan berada 
pada kategori sangat baik dengan total skor 9 , kinerja pelanggan berada pada kategori baik dengan total skor 3,62, kinerja proses bisnis internal berada pada kategori sangat baik dengan total skor 8,79 serta kinerja pembelajaran dan pertumbuhan berada pada kategori baik dengan total skor 19,34.

3. Faktor-faktor yang perlu diperhatikan pada masa yang akan datang adalah tingkat produktivitas karyawan dan kepuasan pelanggan karena skor yang dihasilkan masih rendah walaupun berada pada kategori baik.

\section{DAFTAR PUSTAKa}

Devani, V.; Dian, D.K. (2012). 'Usulan perbaikan kualitas pelayanan administrasi mahasiswa dengan menggunakan metode quality function deployment (QFD).' Jurnal Ilmiah Teknik Industri, Vol. 11 (2), hal. 185 - 197.

Erlina. P. (2009) 'Analisis kinerja perusahaan dengan metode BSC dan SWOT.' Jurnal Penelitian Ilmiah Teknik, Vol. 9 (1), hal. 48 - 57.

Gasperz. V. (1997). Manajemen Kualitas: Penerapan Konsep-Konsep Kualitas Dalam Manajemen Bisnis Total. Jakarta: PT. Gramedia Pustaka Utama.

Gibson, J.L.; Donnely, J.H. (1994). Organisasi Perilaku. Jakarta: Erlangga.

Hidayat, R.; Utami, I.D.; Umayya, U. (2010). 'Tolak ukur penilaian kinerja badan usaha dengan balanced scorecard (BSC).' Jurnal Teknologi, Vol. 2 (2), hal. 90 - 98.

Kaplan, R.S.; Norton, D.P. (2000). Balanced Scorecard: Menerapkan Strategi Menjadi Aksi. Jakarta: Penerbit Erlangga.

Lupiyoadi, R.; Hamdani, A. (2006). Manajemen Pemasaran Jasa. Jakarta: Salemba Empat.

Mulyadi. (2001). Balanced Scorecard: Alat Manajemen Kontemporer untuk Pelipatganda Kinerja Keuangan Perusahaan. Jakarta: Salemba Empat.

Munawir, S. (1993). Analisa Laporan Keuangan. Yogyakarta: Liberty.

Nusraningrum, D.; Waluyaningsih, N. (2013). 'Performance analysis: The case of Directorate General of Civil Aviation using balanced scorecard.' World Journal of Social Sciences, Vol. 3 (3), pp. 98 - 119.

Sugiyono. (2008). Metode Penelitian Kuantitatif Kualitatif dan $R \& D$. Bandung: CV. Alfabeta.

Sutarno, N.S. (2004). Manajemen Perpustakaan. Jakarta: Samitra Media Utama.

Tandiontong, M.; Yoland, E.R. (2011). 'Penerapan balanced scorecard sebagai alat pengukuran kinerja yang memadai.' Akurat Jurnal Ilmiah Akuntansi, Vol. 2 (5), hal. $1-26$.

Tjiptono, F. (2008). Service Management. Yogyakarta: C.V Andi Offset.

Wicaksono, B. (2013). 'Manajemen strategis dalam balanced scorecard pada organisasi publik.' Jurnal Analisa, Vol. 1 (2), hal. $54-61$.

Yamit, Z. (2005). Manajemen Kualitas. Yogyakarta: CV. Ekonisia. 